\title{
EX-ISTO: \\ O OLHAR NO CAMPO EXPANDIDO
}

\author{
EX-IT: \\ THE GAZE IN THE EXPANDID FIELD
}

Danusa Depes Portas

Pontifícia Universidade Católica do Rio de Janeiro, Rio de Janeiro, Brasil

\begin{abstract}
Resumo: A crescente tendência nos estudos dos meios de comunicação pela dimensão transnacional do tráfico e a produção de imagens acompanham o deslocamento dela ao centro dos debates sobre o papel da representação nas culturas globais contemporâneas. Essas questóes consubstanciam-se em problemas-chaves fundamentais: a hibridação dos campos disciplinares da literatura, fotografia, cinema, arte em um contexto internacional; a relação entre a imagem e o arquivo, com respeito à memória, à história, à justiça. No horizonte desses problemas, o trabalho objetiva distinguir o papel constitutivo da imagem do autor na dinâmica da imaginação teórica ocidental e as funçôes políticas dos agenciamentos memorialísticos de que se revela portador, valendo-se da obra de Cindy Sherman como intercessor.
\end{abstract}

Palavras-chave: Cultura visual; regime representativo; dispositivo autor.

Abstract: The growing trend in media studies for the transnational dimension of trafficking and the production of images accompany the her displacement to the center of debates about the role of representation in contemporary global cultures. These questions were objectified in fundamental key problems: the hybridization of the disciplinary fields of literature, photography, cinema, art in an international context; the relation between the image and the archive, with respect to memory, history, justice. In view of these problems, the paper aims to distinguish the constitutive role of the author's image in the dynamics of the Western theoretical imagination and the political functions of the memorialistic assemblages of which they reveal themselves bearers, using the work of Cindy Sherman as intercessor.

Keywords: Visual culture; representative regime; dispositif author.

No estudo empírico de literatura, encaram-se as obras literárias como parte de uma constelaçáo social, isto é, no campo de tensão entre produçáo, distribuição, recepção e processamento. E, quando se trabalha assim com literatura, conforme propóe Siegfried J. Schmidt, só se pode proceder de forma contrastiva com outras mídias. Por exemplo, ponderando o que faz 
a literatura em contraste com as mídias audiovisuais; quais são as possibilidades e fronteiras da mídia impressa; o que significa o incremento de novas mídias no desenvolvimento da sociedade. Quando se observa a literatura como uma mídia entre outras ou como uma forma midiática impressa, considera-se ao lado dela a forma de produção estética de outras mídias. Então entra em questáo a comparação: como se diferenciam os diferentes produtos, que papel desempenham em relação a eles as outras mídias de massa etc. Em vista do exposto, entendemos que a abertura se deu na seguinte direção: dos textos literários à comunicação literária, da comunicação literária como uma parte da comunicação social, e da comunicação social para a comunicação midiática. Esses foram os passos. As diferentes mídias, em consequência, deveriam ser observadas sob o ângulo de qual programa cultural funcionam as mídias. Por isso, observamos que os produtos midiáticos são sempre resultado de um complexo de processos de produção, no qual fatores agem conjuntamente.

Observamos, ainda, uma crescente tendência nos estudos dos meios de comunicação pela dimensão transnacional do tráfico e da produção de imagens que acompanha o deslocamento da imagem ao centro dos debates sobre o papel da representação, da autoria e recepção de literatura/arte nas culturas globais contemporâneas. Essas questôes efetuam-se na preponderância da imagem no regime representativo em vigor, alterando formas de percepçáo e de experiências estéticas, e operam significativos deslocamentos no campo da literatura. A diferença da noção de texto e de imagem não invoca somente uma questáo formal; a disparidade entre a cultura da leitura e outra do espectador incide nas formas de sociabilidade e subjetividade, nos tipos de indivíduos e instituiçóes formadas pela cultura. Essa interação entre imagens e textos é constitutiva da representação em si. O ponto de inflexão aqui parte do princípio de que todos os meios são meios mistos e todas as representaçôes são heterogêneas; náo existem as artes puramente visuais ou verbais, ainda que o impulso de purificar os meios seja um dos gestos utópicos marcantes do modernismo. Consequentemente, torna-se fundamental interrogar a legibilidade das imagens, identificar diferenças em relação às palavras e assinalar a relevância de visar essas perguntas a respeito dos objetos de representaçáo em que aparecem as imagens.

Este ensaio propóe, portanto, uma avaliação de tópico fundamental do campo dos estudos de literatura e cultura, a saber, o dispositivo autor, a partir da sua inserçáo complexa nos debates da cultura da imagem. Tal exame replica a hipótese de que a percepçáo da importância da imagem no modo de produção de saberes na contemporaneidade pode proporcionar a 
emergência de novos modos discursivos de produção de escritos no campo da crítica literária, escrita de histórias de literatura e da cultura, como alternativo ao modo discursivo paradigmático de produção de saberes. Logo, é preciso começar pelo mais extremo.

\section{Heterologia da representaçáo}

O primeiro lugar, diz Hegel, pertence, pela própria natureza das coisas, à arquitetura. Entretanto, nosso projeto nada tem de edificante, preferiríamos abordar o que arruína tanto os projetos quanto os edifícios. Gostaríamos de seguir e fazer funcionar uma fissura que frustre os planos, abale os monumentos. Começaremos pela archè. Mas sem que a archè comande por antecipação um télos que fará desaparecer dele, retrospectivamente, qualquer traço de contingência.

É possível que o conceito de identidade seja um dos mais escorregadios, contraditórios e incômodos conceitos inventados pela modernidade ocidental (porque, de saída, é uma invenção, é moderno, é ocidental). De fato só a assim chamada modernidade - a que deveríamos qualificar modernidade burguesa - requereu esse conceito para dotar de conteúdo interior, em princípio, a outras de suas invenções, fundamentalmente do ponto de vista teórico-ideológico: a figura do individuo. Figura que constitui a base filosófica, política e eco-nômica de toda a construçáo social da burguesia europeia a partir do Renascimento e cuja expressão metafísica máxima articula ao ego cogitans cartesiano do século XVII o sujeito transcendental kantiano do século XVIII. Evidente que essa imagem dominante da modernidade, apoiada na identidade individual, não é a única possível. Há uma imagem crítica da modernidade, contraposta do interior dessa mesma modernidade europeia e exemplarmente expressa pelo pensamento de Marx, Nietzsche ou Freud, que questionam esse universalismo da identidade individual, esse essencialismo do Sujeito moderno.

Semelhante questionamento supóe uma imagem coletiva e fraturada do Sujeito moderno, qual seja, respectivamente, pela luta de classes, pela vontade de poder acaçapada por trás da moral convencional, ou pelas pulsôes irrefreáveis do Inconsciente. Essa noçẫo de identidade é uma representação dos sujeitos, pensada inicialmente para descrever a interioridade individual. Representação - insistimos - relativamente nova e consagrada, no campo da arte, pela propagação do gênero retrato na pintura renascentista, ou do gênero novela na literatura moderna. Essa representação gerada para falar dos 
indivíduos se verifica no âmbito das sociedades e - especialmente a partir do romantismo alemão - se fala também da identidade nacional (o Volkgeist ou espirito do povo seria uma primeira aproximação, até fins do século XVIII).

Trata-se, evidentemente, de outra necessidade burguesa, estreitamente vinculada à construção moderna dos estados nacionais, no contexto do emergente modo de produção capitalista; a representaçáo de uma identidade nacional na qual todos os súditos de um Estado puderam reconhecer-se simbolicamente em uma cultura, uma língua e uma tradição histórica comuns (além de coincidir fisicamente em um território muitas vezes artificialmente delimitado) foi a princípio um instrumento ideológico de primeira importância. E, desde o princípio, as imagens e a lingua - portanto a arte e a literatura, entendidas como instituiçôes - construíram elementos decisivos da dita construçáo (ainda que não se possa reduzir a ela): eram movimentos indispensáveis para o sucesso daquela identificação (leia-se daquele reconhecimento de uma identidade) do povo como seu Estado-nação.

Mas, certamente, a história - isto é, a história de uma representaçáo como a da identidade nacional - não é um processo linear e homogêneo. A quase natural predisposição do capitalismo, e logo da nova classe dominante em ascensão, ao expandir-se mundialmente para assegurar as bases de sua reprodução, teve como rápido efeito (e há inclusive quem, desde a assim chamada teoria do sistema-mundo, assegura que isso foi uma causa e náo um efeito) a promoção pelos Estados europeus da empresa colonial, que não só supóe o mais gigantesco genocídio da história humana, mas também um devastador etnocídio, com o arrasamento de línguas e culturas milenares e sua substituição forçada pela língua, pela cultura e pela religião do Estado metropolitano, assim como a invenção de naçôes coloniais - e, logo, por trás da descolonizaçáo de naçôes supostamente soberanas - ali onde havia outras formas de organização política, territorial, cultural.

Mediante a violência (física ou simbólica), foram transformadas radicalmente as formas de representação identitária desses povos. E as guerras de independência não alteraram substancialmente - não podiam fazê-lo: a destruição já estava assegurada - essa situação. Essas guerras foram levadas a cabo (com exceção da primeira delas, a do Haiti) sob a direção das elites transplantadas, das novas burguesias coloniais que haviam desenvolvido interesses próprios e locais, as quais em geral mantiveram (e ainda aprofundaram com a ajuda das potências rivais da antiga metrópole) a situação herdada da balcanização. E seus intelectuais orgânicos, repetindo forçosamente em condiçóes históricas radicalmente diferentes o modelo europeu, 
aplicaram-se a gerar representaçóes nacionais ali onde não haviam existido de fato naçóes, no sentido moderno do termo.

Isso produziu um extraordinário paradoxo. Se, por um lado, esse processo de definição um tanto artificial de culturas nacionais teve muito de ficção, por outro, cumpriu um papel ideológico nada desprezável (e que ainda hoje está longe de se haver esgotado, apesar de todos os discursos sobre o fim das culturas nacionais sob o império da globalização) na luta anticolonial. Essa tensão, em certa medida irresolúvel, entre as representaçóes fictícias e seus efeitos reais criou, para as novas sociedades assim inventadas, uma situação particular e conflituosa sob a qual a própria noção de cultura nacional se transformou em um campo de batalha, sofreu sucessivos deslocamentos segundo a ideologia, a posição política, étnica ou classista de quem tentou reapropriar-se dessa noção. Mais ainda porque durante os séculos XIX e XX a questão da identidade (isto é, da auto-representação imaginária) nacional ou latino-americana ou africana constituiu um debate político, ideológico e intelectual permanente, em geral - e com as perpétuas exceções - não foi posta em questâo aquela origem ficcional da ideia de uma cultura nacional, que se deu mais ou menos por certa, ainda quando percebida como um terreno de conflito. Quem sabe - é apenas uma tímida hipótese de traba-lho - isso explique o porquê, em toda tentativa de definir uma cultura nacional ou regional, a literatura ou a arte, o universo das representaçóes, têm um papel decisivo. Na cultura latino-americana, pode-se dizer que essas representaçôes literárias e estéticas foram um espaço dominante - e quase atrevemo-nos a dizer: o único relativamente bem-sucedido - de construção de representaçôes identitárias coletivas.

É como se a plena e consciente assunção de uma matéria-prima ficcional fora a forma proeminente de articulaçáo de uma verdade latino-americana que pertence à ordem do imaginário ou do alegórico. $\mathrm{O}$ imaginário coletivo é a via indireta através da qual se articula uma fabulação da verdade social e histórica em seu caráter simbólico. A reconstrução de uma verdade, a partir de materiais representacionais, não é nenhuma operação insólita, mas exatamente a operação descrita por Freud para o funcionamento do Inconsciente, que se ajusta para dizer uma verdade inter-dita (isto é, ao mesmo tempo proibida e entre-dita) mediante textos ficcionais do sonho, o lapsus; e assim a obra de arte ou literária. E seria por essa razão que Lacan, lendo avant la lettre a Freud, pôde afirmar o paradoxo de que a verdade tem estrutura de ficção.

Dito isso, para acentuar as vacilaçôes da relação entre a noção de iden- 
tidade (inclusive no seu sentido coletivo, o que na cultura moderna ocidental, como visto, foi transportado do campo do indivíduo) e a de representação como efeito imaginário e como mecanismo de construção da identidade. Será necessário agora aprofundar esse último conceito, ensaiando algumas analogias sem dúvida discutíveis e arriscadas, mas que poderiam ser assim mesmo produtivas.

Nos últimos tempos, nos temos acostumado a falar de uma profunda crise, que alguns qualificam de terminal, no que geralmente se chama o sistema de representação. Quando falamos assim, estamos falando, evidentemente, da crise da política, inclusive da crise do político, no mais amplo sentido dessa palavra. Mas o termo representação tem o âmbito e o interesse polissêmico de ser um conceito que não pertence só ao discurso da política - ao menos em seu sentido moderno -, mas também ao discurso da estética, da teoria da arte ou da filosofia das formas simbólicas em geral. Podemos aproveitar dessa riqueza semântica para tentar, ao menos na intenção de balbuciar hipóteses, algumas articulaçóes náo reducionistas entre esses campos discursivos baseadas no conceito de representação e sua crise atual.

Para tanto seria necessário fazer um breve rodeio histórico. Carlo Ginzburg (2001), retomando por sua vez algumas ideias de Ernst Kantorowicz em seu famoso estudo sobre The King's Two Bodies (1957), explica que na Idade Média europeia o termo representatio começou por designar as efígies escultóricas, normalmente feitas de madeira, que acompanhavam na procissão funeral o féretro do rei morto. No entanto, se desconheciam as modernas técnicas de conservação do cadáver, o corpo do ilustre falecido era imostrável, seu estado de repugnante putrefação produzia um efeito visual de extrema decadência do Poder real; ou teríamos que dizer, quem sabe, da decadência do real do Poder, transformado em uma massa informe e degenerada, digna de respeito e veneração.

A lógica da representatio, então, enquanto representação simbólica incorruptível do Rei, ao mesmo tempo substitui e é o corpo do Poder. E o faz como toda a ambiguidade do deslocamento chamado metonímico, no qual a imagem re-representada torna presente o objeto representado, precisamente por sua própria ausência, no sentido de que essa ausência do representado - ou sua obscenidade - é a própria condição de existência do representante. Dito de outro modo: a própria condição de possibilidade da existência da representação é a eliminação visual do objeto. Ali onde está a representação, por definição sai de cena o objeto representado. E, entretanto, ao mesmo tempo, a existência virtual do objeto invisível é o determinante último da re- 
presentação. Em toda representação, portanto, se póe em jogo um paradoxo entre presença e ausência. Ou, para dizer em outros termos, entre o visível e o invisível; onde o invisível é parte constitutiva do visível. Mas, certamente, não se trata de qualquer invisibilidade. Se o visível está determinado pelo invisível, o contrário também é certo; o visível produz o invisível como uma determinação concreta e específica de invisibilidade.

Em algumas circunstâncias históricas e sociais, esse jogo de visibilidade/invisibilidade pode ser produzido com objetivos políticos-ideológicos bem precisos, e certamente não somente a serviço do poder, mas, ao contrário, a serviço de uma reconstrução das representaçóes e identidades coletivas com fins de resistência à opressão. Os exemplos são muitos. Entre eles, paradigmática seria a já clássica análise que faz Frantz Fanon (1969) da função do véu entre as mulheres argelinas da FLN (Frente de Liberação Nacional) na luta anticolonial no princípio da década de 1960. Fanon (1969) explica que os funcionários coloniais franceses estavam verdadeiramente obcecados por convencer as mulheres a tirar o véu, invocando razóes progressistas e até de emancipação feminina. Mas a verdadeira razão - analisa Fanon (1969) - é que eles percebem perfeitamente que - sob as condiçóes da ocupação colonial - esse véu, que para os ocidentais ilustrados foi sempre símbolo do submetimento da mulher, é agora ressignificado como índice de resistência cultural: os conquistadores, diz Fanon (1969), sentem que essa persistência, no ocultamento do rosto, equivale a uma fortaleza que náo pode ser conquistada; a mulher argelina pode olhar a seus novos amos sem ser olhada por eles. Há ali uma desaparição da imagem, da representação, que permite que esse corpo não possa ser simbolicamente violado pelo escrutínio permanente do opressor.

Mas, na segunda etapa, com a luta colonial já avançada, a FLN faz com que suas mulheres tirem o véu. Náo, evidente, porque aceitem o mandato do governo colonial; menos ainda com o objetivo principal de eliminar um símbolo vergonhoso da opressão feminina. As mulheres da FLN tiram o véu para se tornarem menos suspeitas, menos misteriosas aos olhos do ocupante - que agora crê ter quebrado essa resistência cultural -, e assim poderem circular livremente, levando em seus bolsos e bolsas ocidentais os panfletos de propaganda ou as armas da resistência.

Essa é a estratégia que Eduardo Grüner, em El sitio de la mirada (2001), chamou de intermitência dialética. Como corresponde a toda dialética, é uma lógica que se desdobra em três momentos: no primeiro, a ausência do rosto segue sendo o sintoma e a afirmaçâo de um domínio, uma 
subordinação ou uma exclusão bárbara. Em um segundo momento, essa mesma ausência seria a negação determinada dessa exclusão: a mulher faz sentir ao civilizado ocupante colonial a presença insuspeitável e inquietante de sua ausência. Em um terceiro momento, o da negociação da negociação, a reapariçáo do rosto - que, paradoxalmente, faz passar a mulher argelina ao anonimato, pelo menos para o invasor - seria o deslocamento (ou melhor, a reversão) do ocultamento dos instrumentos de libertaçáo. Pode-se ver como a alternância, entre presença e ausência das representaçóes do civilizado e do bárbaro, é ressignificada criticamente como uma política de preenchimento dos vazios de representação. Mas essa política monta-se sobre a lógica constitutiva de que falávamos anteriormente, a saber, de que o representante supóe, ao menos a princípio, a desaparição do representado.

O que conecta o representante ao representado é, assim, uma infinita distância entre ambos: constitui a percepção de dois mundos que nunca poderiam coexistir no mesmo espaço e cuja relação consiste exatamente nessa diferença radical. Há aqui uma coincidência, que não podemos deixar de assinalar na sequência, com outra famosa noçáo benjaminiana, a de aura da obra de arte clássica, cuja idealização (que Walter Benjamin compara com o estado de enamoramento) implica assim essa aporética experiência de uma estreita identificação e uma imensa distância, simultâneas. E já sabemos qual é uma das hipóteses centrais desse ensaio de Benjamin: que poderia ser elaborada toda uma história social e política da arte, e, portanto, do conceito de representação (inclusive sua função na construção identitária) sobre o eixo das sucessivas transformaçóes históricas e antropológicas dessa experiência da aura, desde seu caráter cultural (ritual e religioso), passando por sua transformação em mercadoria até chegar ao que Benjamin chama a decadência da aura sob a lógica das modernas técnicas de reprodução.

Voltemos aos avatares da representatio medieval, imaginemos por um momento um improvável acidente: durante a procissão, o féretro contendo o corpo real, material, do soberano cai no chão e rompe-se, exibindo esse corpo corrupto e obsceno. Não sucederia então que a própria eficácia metonímica e simbólica da operação de representatio, que havia permitido transladar o emblema da realeza e a realidade do Poder à efígie-representante, agora transladaria até a própria efígie, até a própria representatio, toda essa contaminante corrupção e obscenidade? É essa restauração da proximidade, esse retorno do real impedido pela representaçáo que resultaria entáo insuportável e odioso, já que a anulação daquela distância idealizada poderia exibir o engano prévio sobre a incorruptibilidade do Poder. E talvez seja isso o que está no fundo dessa reiterada conduta iconoclasta de toda revolução 
ou rebeliāo contra o Poder, que consiste em destruir as efigies, derribar as estátuas, incendiar os edifícios ou profanar os retratos de quem tem representado o Poder.

Enfim, prossigamos com nossa alegoria. Outro grande historiador da arte da escola iconológica, Erwin Panofsky (1973), instrui-nos sobre um câmbio importante nos próprios critérios de representação estética, o qual se produz na passagem da Idade Média ao Renascimento. Enquanto a representação medieval, como acabamos de ver, mantém simultaneamente uma identificaçâo e uma distância com o objeto representado - a efígie é imediatamente o corpo, mas ao mesmo tempo sua existência e seu valor emblemático dependem de que o corpo se mantenha ausente, fora de cena (expressão que traduz etimologicamente o vocábulo obsceno, que alude ao ato de mostrar o que deveria ter permanecido fora de vista) -, a arte renascentista - com sua descoberta da perspectiva, com seu impulso mimético e realista - apropria-se do objeto, substitui, como toda representação, sua presença física e material, mas também, ilusoriamente, substitui e, portanto, elimina sua ausência. Sua pretensão em última instância é a fusão da representação com o representado, conservando a identificação, mas eliminando, imaginariamente, a distância.

Há aqui também, sem dúvida, uma obscenidade, mas que se encontra, por assim dizer, legalizada: a mudança de época começou já a produzir sua própria distância entre o sujeito e a natureza; separaçáo que, entre outras coisas, fará possível a ciência moderna, mas também a uma atitude puramente contemplativa frente à arte e às representaçôes, enquanto na Idade Média as representaçóes - tanto as religiosas com as políticas - tomam parte de uma expressão relativamente cotidiana, de uma paisagem social indiferenciada e ainda desconhecedora das esferas autônomas próprias da modernidade - o capitalismo. Já foi dito que um dos componentes decisivos dessa mudança na imagem do mundo é a promoção do protagonismo do indivíduo, expresso na história dos estilos artísticos por prestígio, renovado na modernidade, do retrato. Essa mudança fica ainda mais patente na utilização da perspectiva nos retratos a partir do Renascimento, em que agora o indivíduo (essa nova categoria da era proto-burguesa) é mostrado em primeiro plano em relação ao seu entorno, enquanto na representação medieval típica, com seu caráter igualador-a-mente plano e sem profundidade, o ser humano fica também aplanado, submergindo no continuum da imagem, de maneira simular a como, na concepçáo ideológico-filosófica dominante na época, o ser humano - toda sua identidade - ficava submerso no continuum da transcendência divina. 
Mas a nova época requer uma nova ideia da legitimidade do poder, feita possível por aquela mudança de identidade. Essa nova ideia, essa nova ideologia, está fundada no contrato laico entre os indivíduos como tais. Por isso, o indivíduo tem que ser posto no centro da cena, no centro de uma cena toda organizada ao redor dessa centralidade individual. O resgate renascentista da consigna antropocêntrica, o Homem como medida de todas as coisas, adquire assim uma nova significação que poderia traduzir-se, não sem certa violência, mas com bastante aproximação, pela fórmula: $o$ indivíduo é o pretexto central da lógica econômica, política e cultural da sociedade burguesa.

Em termos da lógica econômica - do que Marx chamaria as relaçôes de produção -, é a vontade do indivíduo o que leva ao intercâmbio de mercadorias, incluindo essa nova mercadoria essencial para o funcionamento do sistema, que se chama força de trabalho; em termos da lógica política, é a lógica da liberdade do indivíduo a que o leva a fazer-se representado no Estado, no qual cada indivíduo delega a administração de seus direitos naturais; em termos da lógica cultural, seria o olhar do indivíduo o que organiza o grande espetáculo do universo desde a centralidade da perspectiva.

Nas formas de representação visual e estética da modernidade não só há indivíduos, sujeitos humanos, mas também, e cada vez mais, objetos da realidade. Neles é a perspectiva geométrica da visão individual do espectador a que concentra a atençáo no objeto como espetáculo e como objeto de potencial apropriação, uma vez que entramos na era em que a propriedade é o critério fundante de toda a estrutura socioeconômica e política. Jonathan Crary (1992), em Techniques of the Observer. On Vision and Modernity in the. Nineteenth Century, analisa com extraordinária agudez como a extrema impressão de realidade pelas tecnologias modernas faz com que os objetos apareçam ilusoriamente como palpáveis, como desejáveis, induzindo a vontade de apropriar-se deles. Para isso, ele se apoia na crescente ilusão também permitida por essa técnica realista, de uma coincidência entre o representante e o representado, onde tende a se dissolver a função simbólica, metafórica ou alegórica da própria representatio.

O realismo, convertido assim na ideologia estética hegemônica (e seguramente não seria a única maneira de pensá-lo), é nesse terreno o pendant exato do individualismo; da perspectiva do indivíduo que a realidade se organiza como espetáculo a consumir. $\mathrm{O}$ termo consumir seria, aqui, chave. $\mathrm{O}$ eixo da imagem da realidade passa da esfera da produção à esfera do consumo. Como gostava de ironizar Marx, a burguesia está disposta a admitir que sempre houve história, que o mundo sempre esteve submetido a mudanças 
permanentes, até que ela chegou. A mesma separação entre o sujeito e o objeto - como dizia - torna possível uma forma de representação na qual, no limite, toda realidade está - como dito - já feita e disponível para sua captura pelo representante.

Estamos, sem dúvida, ante uma transformação ideológica de primeira importância, a qual trata de dissimular a brecha, a diferença irredutível, entre o representante e o representado, que antes se dava como certa. A representação começa, a partir daqui, a ocupar - atrevemo-nos a dizer, usurpar - o lugar do representado, com o mesmo gesto com o qual se inaugura o critério de representaçấo como presença do real-representado, enquanto o critério anterior era, como visto, o de sua ausência. Uma metafísica da presençacomo tem sido chamada - que alcança a própria autorrepresentaçâo subjetiva a partir de um Eu cartesiano que aparece como presente ante si mesmo, fonte clara e distinta de todo conhecimento, transparência e possibilidade, e cujo desmentido em breve chegará -, ainda que sem registrar repercussóes decisivas nas teorias políticas e sociais hegemônicas da teoria psicanalítica do Inconsciente, com a famosa terceira ferida narcísica infringida por Sigmund Freud a uma humanidade (ocidental), que previsivelmente nada quer com isso, e que, talvez, não por azar, coincida com a crise e a fratura dos modos de representaçáo preponderantes do princípio do século XX.

Isso sem mencionar, desde o ponto de vista sócio-histórico macro, o ocultamento - mediante a abusiva presença representacional do Ocidente que, a partir da modernidade, se erige como cultura universal - do lugar fundante, mas impedido que os Outros ausentes (para começar, o mundo colonizado inteiro) têm na própria autoimagem desse Ocidente dominante.

Basta para nossos propósitos mencionar que a modernidade filosófica é marcada, nos manuais ao uso, precisamente no século XVII, com a representação identitária desse sujeito cartesiano monádico, encerrado em sua própria transparência e em sua própria presença ante si mesmo, que será o núcleo durante séculos de toda teoria da representação, tanto simbólica como estética e política. Muito diferente seria tal representação se aquela história filosófica da modernidade - inclusive a ocidental - iniciasse um século e meio antes, por exemplo, com a conquista da América e dos debates entre Bartolomé de las Casas, Francisco Vitoria, Juan Ginés de Sepúlveda e muitos outros sobre o estatuto de humanidade desses Outros subitamente incorporados a (ou violados pela) modernidade europeia. Já não teríamos ali entâo essa representação cartesiana que funda a subjetividade moderna sobre o solipsismo auto-engendrado do sujeito monádico - e que se translada 
facilmente ao mito de auto-engendramento dos Estados e naçóes da Europa moderna -, mas uma representação estritamente dialógica, atravessada pelo conflito permanente e instável implícito no diálogo dos sujeitos coletivos e das culturas: uma representação que, mutatis mutandis, estaria em um contrassenso muito mais perto da representaçáo freudiana (e, a sua maneira, marxista) da subjetividade moderna, que da pacífica autorreflexividade e autorreferencialidade do EU cartesiano - ou, ao menos, da vulgata ideológica interessada que o Eu cartesiano terminasse se impondo. Uma representação descentrada que parece estar paradoxalmente prenunciada na excentricidade do Barroco; paradoxalmente porque, como se sabe, o impulso ideológico por trás da representação barroca é - dito em termos clássicos - reacionário. $\mathrm{E}$ não seria a primeira vez na história que uma reação contra o presente que pretende voltar ao passado permite entrever as potencialidades do futuro. Transformação ideológica, dizíamos antes. E também, claro está, política.

Posto que - como já adiantado - é possível esquecer que a época que institui a representação com seu valor pleno de realidade, corresponde ao período de constituiçáo do Estado Moderno (ocidental), que - cumprida sua etapa de transição com maior ou menor grau de absolutismo - consagra a forma de governo chamada representativa e o sistema político correspondente. É também impossível, então, subtrair-se à tentação da analogia constitutiva - como se costuma dizer. O sistema representativo produz o efeito imaginário de suprimir a diferença representante/representado, diferença objetiva sem a qual, paradoxalmente, o próprio conceito de representação carece de sentido.

Sabemos que, antes disso, como modo inconsciente de maquinar essa crise, a eliminação e já não só a substituição - do objeto pela representação foi levada a suas consequências extremas pelo que foi denominado pós-modernidade, quando a dominação das forças produtivas e reprodutivas das novas tecnologias da representação - dos meios de comunicaçáo em massa, a web, para rotulá-las rapidamente - fizeram-nos passar da identificação entre o representante e o representado, características da modernidade, a uma desmaterialização globalizada do mundo pela qual até as guerras mais atrozes puderam reduzir-se a um colorido espetáculo televisivo atrás do qual parecia não haver nada, apenas um imenso vazio em que os objetos e, sobretudo, os corpos destroçados pelas bombas ficaram já não só fora da vista no ataúde de conteúdos i-mostráveis, mas deslocados ao infinito, a uma distância inacessível em que se perde para sempre a relação conflituosa, sim, talvez impossível, mas relação enfim, entre a imagem e o objeto. Será por isso que nunca vimos, em imagens, os corpos mortos na Guerra do Golfo, nas Torres 
Gêmeas ou no Afeganistão?

Isso tem seu correlato tanto no plano da economia como no da política. $\mathrm{Na}$ economia, a transformação da lógica produtiva do capitalismo industrial clássico na lógica parasitária da especulação financeira. Na política, a desmaterialização da democracia representativa, forma que também aumentou ao infinito sua distância com os representados, até eliminá-los quase por completo como dados de realidade transformada em pura virtualidade, na qual a chamada classe política vive alienada em sua própria auto-representatividade vazia. O colapso das formas de representação da economia, da política e da própria arte serão indicadores, ou ao menos sintomas, de um retorno do real que induz, em todos esses campos, também a um regresso ao realismo; um regresso da matéria representável?

Nada disso podemos saber. Acontece, por exemplo, que os ataúdes caem ao chão e se rompem, e o corpo putrefato do Poder fica exposto em toda sua terrificante obscenidade. E, quando acontece isso, sabemos que a representatio morta deve ser re-fundada entre todos, porque nos vai à vida, e não somente - ainda que não seja pouca coisa - a representaçáo que dela fazemos.

\section{A imagem que se diz-(d)obra}

Nos anos 90, trinta anos depois da morte do autor anunciada por Roland Barthes e Michel Foucault, fomos testemunhas de um estranho renascimento do autor como zumbi, a mise en scène de uma condição paradoxal de autoridade ausente. Ainda: circunstantes do desvio como força criadora da crítica.

Nas séries fotográficas de Cindy Sherman, pode-se perceber uma reivindicação contemporânea da circulação de imagens e de media dominada pela dinâmica da cultura da imagem. Sherman é uma colecionadora recitando toda uma cultura visual, sua obra constitui um inventário de motivos e procedimentos. Suas séries são urdidas de forma a mostrarem-nos as próprias condiçốes de surgimento e de recepção, um dispositivo de inscrição e escritura que coloca em situação, numa estratégia complexa, fotógrafo e observador. Promovendo deslocamentos e transferências entre fotografia, cinema e arte, Sherman constrói uma metalinguagem com a qual pode então operar em um plano mito-gramático da produção artística, apontando um modo de articulação entre maneiras de fazer, formas de visibilidade dessas 
maneiras de fazer e modos de pensar suas relaçôes.

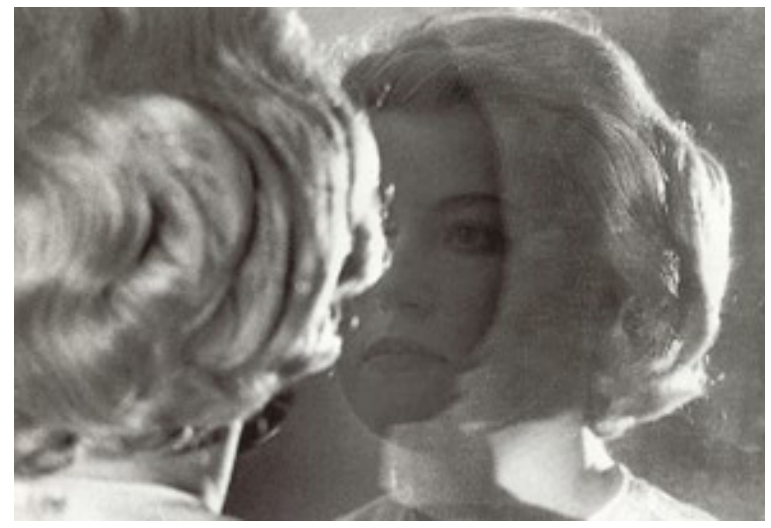

Figura 1: Untitled Film Still \# 56, 1980, Cindy Sherman

Fonte: https://www.artic.edu/artworks/72442/untitled-film-still-56

Os Untitled Film Still, Cindy Sherman são precisamente sobre a transformação de vidas vividas em vidas produzidas mecanicamente, como a indústria dos sonhos produz nada mais do que clichês irresistíveis que introjetam compulsivamente, até o ponto em que não há nenhuma vida que tenha sido previamente empacotada e inscrita, contada, determinada, subsumida. A indústria dos sonhos, mais do que fabricar os sonhos dos consumidores, introduz os sonhos dos produtores em meio às pessoas. A reificação não é nenhuma metáfora: ela faz com que os seres humanos que reproduz se assemelhem às coisas, mesmo onde os seus dentes não representam pasta de dente e suas rugas de preocupação não evocam laxativos.

Quem quer que vá a um filme está apenas esperando pelo dia em que esse feitiço seja quebrado e talvez, no final das contas, apenas essa esperança bem guardada leve as pessoas ao cinema. Mas, uma vez lá, elas obedecem. Elas se incorporam ao que está morto.

Muitas imagens da série Untitled Film Still (THAMES; HUDSON, 1997), se não a maioria delas, apreendem uma personagem no meio da ação, de modo que, pela imaginação, projetamos na cena uma estrutura narrativa, a própria narrativa, por assim dizer, da qual a cena foi retirada. 


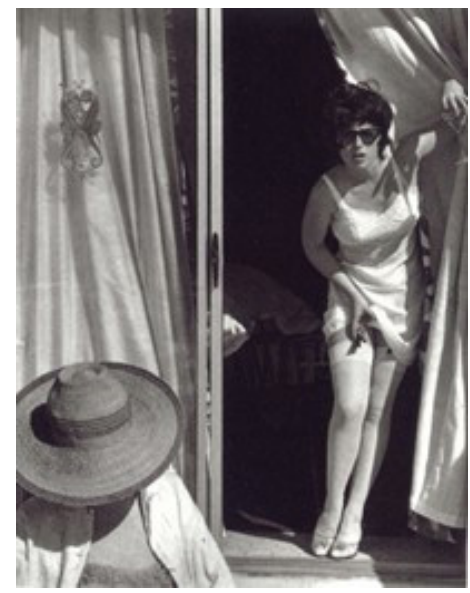

Figura 2: Untitled Film Still \# 7, 1978, Cindy Sherman

Fonte: https://www.moma.org/collection/works/56540

Mas, é claro, não há nenhuma narrativa aqui, nenhuma história, tudo já está decidido. A narrativa, o filme que passamos mentalmente, é uma cena, parada e congelada; portanto a temporalidade desdobrada, que pretende ser a prerrogativa do filme sobre a fotografia, é uma falácia. A verdade da temporalidade do filme é a cena. E essa redução pretende contar algo contra o filme e a fotografia. Sendo captada por um clichê, uma cena, cada personagem retratada está decretando uma mimese com a morte; elas são o veículo e a vítima do clichê que exemplificam. Portanto, cada fotografia é a mimese dessa mimese com a morte.

A partir disso, parece necessário inferir (uma inferência exigida, de qualquer modo, pelas últimas obras de Sherman) que a artista não tinha a intenção de que as séries fossem uma posição em favor da tese de que o eu náo é nada mais do que um tecido de clichês, nada mais do que um portador de significaçôes culturais. Pelo contrário, essa tese é seu alvo, o que ela pretende estar interrogando e negando. Por todas as suas referências nostálgicas ao passado recente, todo o seu charme, astúcia e conhecimento, há algo de desconcertante e escuro sobre os Film Still. E é no território de sua escuridão que reside sua autoridade enquanto obra.

Podemos, por hipótese, pensar que os Film Still, de Cindy Sherman, apesar do fato de a artista figurar em todos eles, não são autorretratos. Ela é 
sua própria modelo e, como é o caso com todas as modelos, isso não a torna o tema de sua arte. Ela não se rende ao desejo voyeurista que provoca. Ela é o objeto do olhar do observador, mas também o controla, por dirigi-lo como fotógrafa. Como artista, ela está no comando total de suas intençôes. Como sua própria modelo, ela abriga clichês intensificados. Entretanto, esse raciocínio parece enganoso.

Se Sherman tivesse feito apenas um Film Still, seu efeito não seria o ocasionado de fato por essas fotografias - somente o efeito de um ato esperto de personificação. $\mathrm{O}$ fato de cada still fazer parte de séries indefinidamente longas, cujo poder cumulativo depende de cada momento da série ser só um clichê, é constitutivo para a força de cada retrato. E cada retrato, cada captação de um sujeito por um clichê, é uma captação de Cindy Sherman.

Parte da dificuldade e fascinação de Film Still é que estamos intensamente cientes de que testemunhamos Cindy Sherman em cada um, além das personagens retratadas. Portanto, o que começa como admiraçáo de sua habilidade de personificaçáo e disfarce, por uma aparente mobilidade e identificação de seus aspectos, que lhe permite abordar um grupo de personagens tấo divergentes, torna-se cada vez mais uma situação de ansiedade. E aqui começa a importar terrivelmente que se trata de fotografia, e, como tal, permanecerá a indexaçáo casual do retrato ao original - a máscara mortuária do objeto original. A indexaçáo do retrato ao original é o que transforma o sentido do que quer dizer ser um modelo para a pintura e a fotografia. $\mathrm{O}$ que existe a mais em cada fotografia, a força expressiva da vulnerabilidade que relaciona a personagem ao clichê e Sherman à personagem, o excedente que deve ser chamado de presença animista do sujeito, sobre e além de sua captação no clichê, volta-se precisamente para o excedente de cada conteúdo explícito, além do artifício, que é uma consequência da combinação do olhar mecânico da câmera (cada um indexado por causalidade a Cindy Sherman como autora), e a proliferaçáo de imagens, cada uma delas fazendo parte de uma série indefinidamente longa. Por fim, o que constitui o fato mais perturbador e insólito acerca das séries é que elas não podem ser nada além de autorretratos. A proliferação de auto-imagens feita por Sherman consegue chegar à sua força persistente, exemplificando o desejo de si em cada uma das formas inadequadas que o negam.

A infinidade viciosa da sujeição pertencente à indústria cultural está recitada e representada nas séries, a fim de revelar tanto a infinidade viciosa por si mesma, quanto o fato de que em virtude da repetição da repetiçâo, a própria Sherman é aquele limite extremo, o excedente que abre caminho 
através do olhar estetizante da câmera, o brilho, a sedução e a aura de cada clichê. A não ser que essas fotografias fossem autorretratos, não seria possível abrir caminho.

É fácil ver o porquê dessas fotografias serem apropriadas tão prontamente para metas pós-modernas. Sugerindo que a força dos Film Still é um animismo, e identificando esse animismo como momento de excesso ou abertura de caminho além da imagem, está implicado um pathos. Esse pathos deve ser considerado como uma consequência da indexação casual da imagem ao fato, chamemos assim, de Sherman por si mesma. Ela só pode aparecer como efeito reflexivo e não como imagem, o efeito de sua reiterada aparição com cada retrato, esse excesso dentro de cada repetição.

Em seus trabalhos dos anos 1980, Sherman procurou reanimar e re-materializar, encontrar representaçóes da vida que resta a ela e a nós, interrogar o que é vivo e o que é morto nela e em nós. Ao procurar representaçôes do que foi ignorado ou considerado indigesto, por obra da indústria cultural, ela se volta inicialmente, sem surpreender, para a fantasia, para a nossa imaginação do que ainda resta além do clichê cultural, deixando a fantasia de uma outra vida se fundir apenas lentamente com a tentativa de imaginar exatamente a vida dizimada.

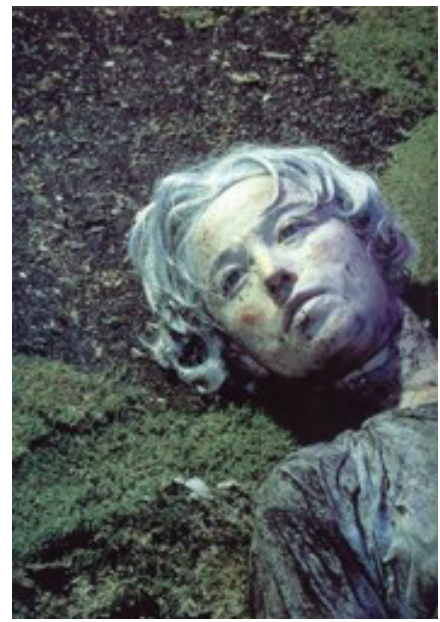

Figura 3: Untitled \#153, 1985, Cindy Sherman

Fonte: https://www.moma.org/collection/works/56490

Untitled, \# 153 da série Gleams and reflection (THAMES; HUDSON, 
1997) toca-nos como sendo apenas mais uma cena de filme com o contraste da face da morta e a grama perfeitamente verde, lama e sujeira sugerindo que há uma falta terrível aqui - toda a vida está no verde e toda a morte no ser humano. O que torna essa fotografia inquietante é a ausência de horror, a ausência do evento devastador que ocasionou essa conclusão composta. A quietude composta da cena ecoa o olhar calmo, embelezador, da câmera (ele mesmo um eco quieto da beleza da escultura clássica).

Compare-se isso com a obra Untitled, \# 177 da série Disasters (THAMES; HUDSON, 1997). Envolvê-la também compóe uma narrativa; talvez um filme de terror realista, um filme de impacto. A morte, o estupro, a violação, o terror prestes a acontecer e acontecendo, nada disso está ali; talvez porque, vendo essas coisas, não veríamos o que é preciso, ou porque as vemos com muita frequência e de um modo equivocado. Em vez disso, temos de encarar a face no canto direito, com o olhar fixo em nós; a face encontra-se escurecida por sombras roxas e azuladas, um pouco fora de foco; não está claro se essa é a face de uma pessoa viva ou morta, se é a assinatura de Sherman, a aparição fantasmática do corpo violentado.

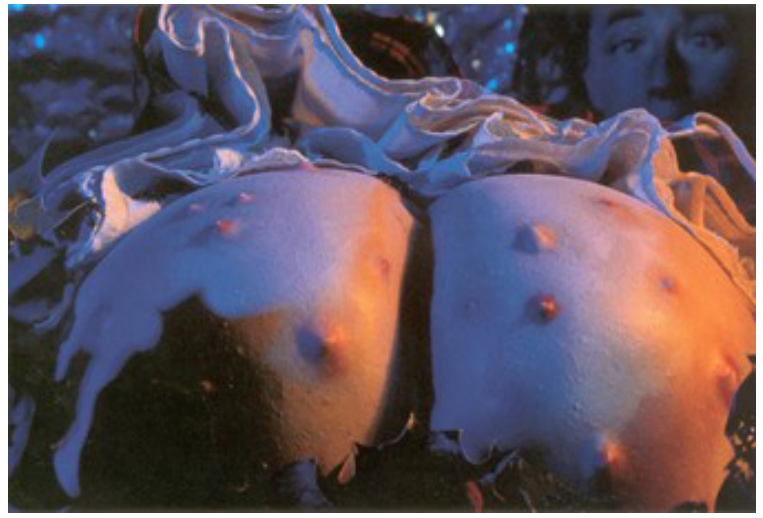

Figura 4: Untitled \#177, 1987, Cindy Sherman

Fonte: http://www.artnet.com/artists/cindy-sherman/untitled-177-odEL6cdd5KPxkMqlLH-

Dkpg2

Cada uma dessas fotografias é objeto coercitivo da atenção visual, espetáculos sem receita de cor, fantasia, ansiedade, os quais, em seu momento exuberante, alucinatório, de excesso sensorial e dissonância, conjuram e instituem um animismo resplandecente, mas algo muito distante da face humana ou da figura humana: trata-se de vida fora do lugar, espinhas nítidas, 
e uma longa língua carnuda que agora suporta toda a carga da afirmação de que a vida vive. No extremo dessas séries, encontram-se as imagens de decadência e as que empurram a questão da vida para o limite de indeterminação entre o orgânico e inorgânico. Talvez o retrato \# 190 seja o mais incisivo deles, já que inevitavelmente nos faz referência às miríades de faces que eram e não eram Cindy Sherman nas Untitled Film Still. Qual o significado de uma face humana que pode ser ou tornar-se tão sem face? O que está nos olhando de volta numa face que foi subsumida por um clichê? O que é uma face humana viva agora? Face a face.

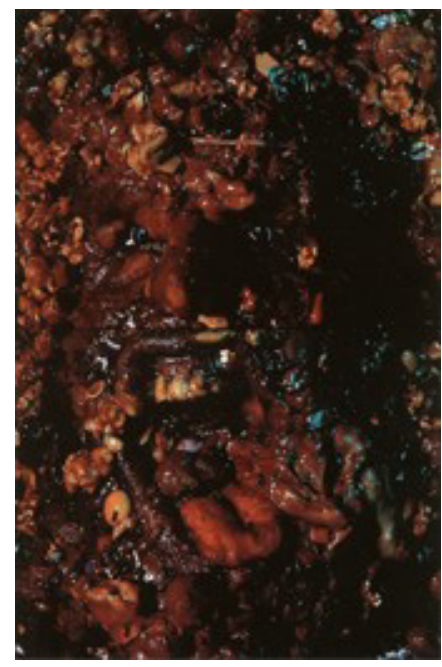

Figura 5: Untitled\#190, 1989, Cindy Sherman

Fonte: https://www.thebroad.org/art/cindy-sherman/untitled-190

O primeiro aspecto que se nota em Untitled \# 190 da mesma série (THAMES; HUDSON, 1997) é sua superfície viscosa escura; trata-se de adornos e enfeites visuais que, como o brilho na superfície da própria foto colorida, chamam atenção do nosso olho ingênuo. Como é fácil fazer um truque para que olhemos! Como é casual a nossa compra do espetáculo visual. Mas isso tudo é superfície, e a superfície é bosta. Se olharmos mais demoradamente, trata-se de algo manchado, dentes brancos e língua avermelhada cobertos com excremento, o que pensamos que deve ser excremento, a imagem exata do indigesto, do qual não podemos tirar os olhos. A nossa fascinação inicial se desdobra em desgosto, que fica em suspenso na fascinação. Será 
que essa face, com seus olhos azuis como os lampejos indeterminados de onde o azul vem, está enterrada na sujeira do cólon ou emergindo para fora desta? Talvez se quisesse dizer, sobre essa imagem, que a sua feiura é demais, próxima demais do clichê do que é horrível para ser realmente revoltante, e que enfim ela é quase cômica, terror kitsch, uma fonte de riso dificultado e muito presente. Mesmo se isso for verdade, não é igual ao horror cômico dos filmes de terror clássicos, pois, seja vendo a imagem como algo que desgosta de verdade ou como algo que desgosta comicamente, ficamos com uma impressão: a cena do excremento é o hábitat natural à face humana.

Ao sugerir que a cena do excremento é o hábitat natural à face humana, estamos querendo despertar interesse pela alegaçáo de que se trata de um estrato de significado, não de um real além do significado, mas de um local de significado, onde esse começa. Trata-se do lampejo de luz tornando-se o lampejo do olhar, a vida emergindo do lodo e mergulhando nele novamente, no grito de horror, ou agonia, ou desgosto, por meio do qual a natureza revoltante se torna um objeto (ou objeto que estamos olhando), torna-se algo que fica em suspenso, ou oposto, ou diferente de nós, mas faz parte de nós: afinidade fantasmagórica.

Compare-se essa maneira de pensar sobre e reagir a Sherman com Norman Bryson (1993). Ele argumenta que o corpo é tudo aquilo que não pode ser transformado em representação, e por essa razão nunca é reconhecível diretamente: se devêssemos fazer o retrato desse discurso-fora-do-corpo em nossas mentes, não se assemelharia de modo algum a um corpo, já que o corpo-como-semelhança é precisamente aquilo a que não é possível convertê-lo. Assim como a linguagem, a representação visual só pode encontrar análogos e termos de comparação para esse corpo: é como isso ou aquilo. Nos limites da representação, ou atrás dela, paira um corpo de que você ficará sabendo apenas por causa desses posicionamentos inadequados, que estáo ali simplesmente para marcar um limite ou fronteira da representaçáo, capazes de conjugar uma penumbra, ou algo que fica além da representabilidade. A penumbra indica que o discurso-como-visão não pode detectar muito bem essa regiáo, nem colocá-lo em foco.

Esse discurso repetiria as mesmas suposiçóes sobre o significado que são a causa e raiz da violência do discurso criticadas pelas imagens de Sherman? O contraste entre representação e real assume que nós - subjetividade, linguagem, práticas discursivas, enfim, como se queira chamar - somos o local ou origem, ou fonte auto-suficiente de todo significado e sentido, que as nossas capacidades de falar e significar talvez sejam condicionadas por um 
substrato material, mas não são dependentes desse substrato. Nós impomos significados ao mundo, nós o damos.

Então, quando Bryson sugere que os manequins e as partes do corpo de estudos médicos, assim como as próteses não podem estar à altura do afeto que produzem, não podem igualar esse afeto, podemos muito bem perguntar: de que tipo de falha se trata? O que é fornecer uma representaçáo, uma mimese de dor, ou terror, ou violação? Será que a linguagem chega a igualar os afetos que produz? E o riso? Que espécie de equiparação está tendo lugar nesse caso? Será que o desafio dessas imagens não é apenas o fato de o momento de significação ser o momento de excesso, o fato de que a interpretação visual é conservada e completada no modo não-discursivo? À medida que nossos conceitos, e suas distinçôes (humano/ não-humano, vivo/ morto, irreal/ muito real), caem por terra, só então a cena se torna presente. Observe a imagem \# 175 também da série Disasters (THAMES; HUDSON, 1997):

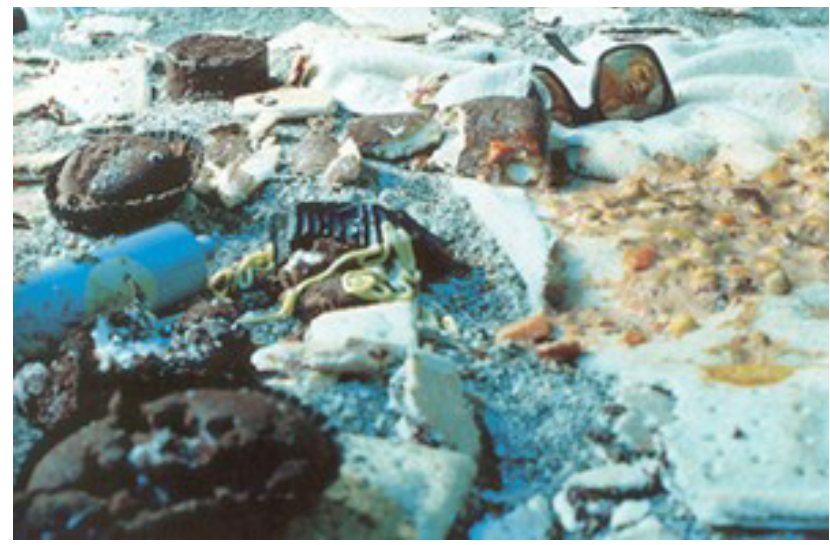

Figura 6: Untitled \#175, 1987, Cindy Sherman

Fonte: https://www.christies.com/lotfinder/Lot/cindy-sherman-b-1954-untitled-175-5994787-details.aspx

O que Sherman apresenta vai além do regime de representação racionalizada da indústria cultural, além do que é estabelecido como formaçôes de significado e importância. O que re-emerge daquele desaparecimento mesmo (o do próprio corpo de Sherman como sujeito/ objeto) é tudo, sobre o corpo, que a torrente de imagens joga fora a fim de manter as ideias do corpo como socializado, limpo, representável: a densidade material do cor- 
po, suas tendências e pulsóes internas, as convulsóes de suas dores e prazeres, a espessura de seu deleite. Enquanto espinhas nítidas, língua tosca, sujeira de cólon são substitutos para esse real e imagens dele; no contexto da obra de Sherman, eles não são o que está além da representaçáo, mas sua própria origem contingente. Não só abrem caminho através do conhecimento racionalizado, mas também forçam sobre nós, com insistência aterrorizante ou cômica, uma outra cena de conhecimento: o que náo podemos engolir, ingerir, provar, equivale àquilo de que não podemos duvidar. A ilusão de domínio racional, ou o jogo do signo, é minada em uma instância de reviravolta cognitiva obrigatória. O terror é uma das formas de arte que Sherman emprega a fim de permitir a fala dessas outras. Ou, pode-se dizer, Sherman dispóe o terror como um modo ou maneira de abstração (ou revela que o terror foi isso o tempo todo), e assim de desrealizar o dado, removendo o significado determinado e doação objetiva, a fim de lhes fornecer uma insistência ilusória que devolve uma força para originar. As afinidades são indexadas empiricamente e ligadas historicamente - são a consequência do mecanismo, da discursividade, do implacável clichê. Sherman oferece um novo material a priori e, desse modo, algo que relembra a experiência para além do que a experiência se tornou.

Com certeza estamos operando no domínio da arte e da ilusão - a sujeira do cólon é, ainda bem, sem cheiro e sem gosto - e, na vida cotidiana, essas fontes naturais, porém antropomórficas, de significado foram excluídas, como demonstra a mini-história foucaultiana do desaparecimento do corpo. Mas é isso que ergue os suportes para a outra cena do ato de conhecer. Embora se trate de um espaço de ilusão, a foto de Sherman remete-nos enfaticamente a um excesso sensorial e corpóreo, do qual o desgosto e/ ou o riso são uma marca, como a imagem a seguir da série Sex pictures (THAMES; HUDSON, 1997). 


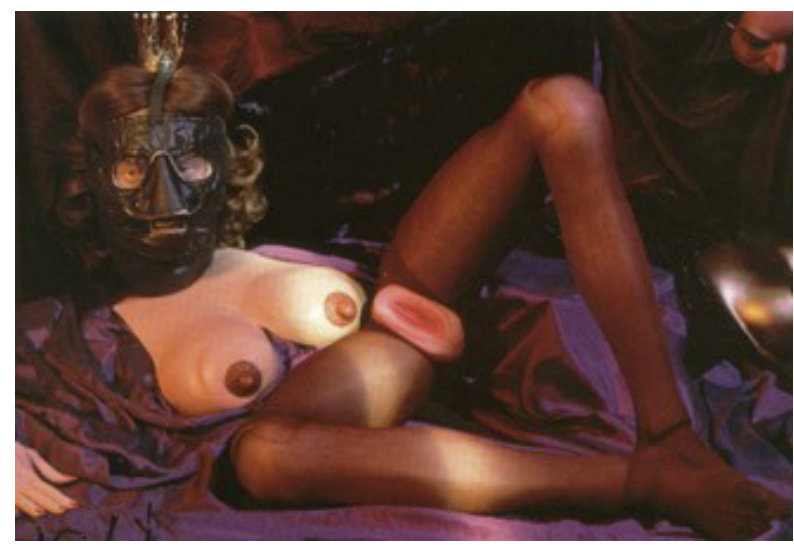

Figura 7: Untitled \# 264, 1992, Cindy Sherman

Fonte: https://www.guggenheim.org/artwork/10791

Os desdobramentos dessas qualificaçóes constituem a primeira tentativa, muito breve, de reconhecer o caráter absolutamente ilusório desses retratos, enquanto se prendem a profundidade de sua insistência sobre a natureza material, ilegítima e abusada. Quero sugerir que a insistência indutiva de Sherman toma o lugar, assim, da função das séries na arte modernista, isto é, o mecanismo de entrar num novo registro, que se prende revelador ou exemplar. É muito tarde para isso: o desastre já aconteceu, e nenhuma obra pode ser exemplar agora. A esse respeito, a indução de Sherman depende, para ser plausível, náo só das séries de filmes de terror/ desastre/ sexo, mas também de tudo aquilo que conduz a eles, desde as Untitled Film Still, passando pelos retratos de moda. Temos imagens inversas da mesma coisa: clichês externos, carnificina interior. Isso é a sequência indutiva, mas apenas em virtude da sequência é que nós, incluindo Sherman, podemos ver a indução envolvida aqui, o caráter de autenticidade da sua insistência. E essa insistência, afirmamos, envolve algum tipo de encontro presente com a sensorialidade, embora ilusória, muito mais do que alguma argumentação sobre sensorialidade ou corporificação ou natureza ou espontaneidade. Tal argumentação seria filosófica e não arte. O fato de as obras de Sherman serem objetos de desgosto ou riso (mais do que de prazer), e essas reaçóes sustentadas como substituições do prazer estético, medem a distância entre filosofia e arte. Mas apenas em virtude da insistência indutiva de Sherman é que isso pode ser visto, as perdas envolvidas podem ser calculadas e la- 
mentadas. É quase certo, então, que a nossa argumentação, aqui, mutila e limita demais o argumento dela: fazer do próprio autor uma imagem (lugar da não finitude); cuja implicação ética é justamente colocar-se como essa opacidade, essa finitude.

\section{Referências}

CRARY, Jonathan. Techniques of the observer - on vision and modernity in the nineteenth century. Londres: MIT Press, 1992.

FANON, Frantz. Sociología de una Revolución. Mexico: Era, 1968.

KRAUSS, Rosalind; BRYSON, Norman. Cindy Sherman 1975-1993. New York: Rizzoli, 1993.

GINZBURG, Carlo. Olhos de Madeira. Nove reflexôes sobre a distância. São Paulo: Companhia das Letras, [1957] 2001.

GRÜNER, Eduardo. El Sitio de la Mirada. Buenos Aires: Norma, 2001.

PANOFSKY, Erwin. Renacimiento y renacimientos en el Arte Occidental. Madrid: Alianza, 1973.

THAMES; HUDSON. Cindy Sherman-Retrospective. London: Thames \& Hudson, 1997. 